\title{
ANALISIS KAJIAN HADITS TENTANG METODOLOGI PEMBELAJARAN RASULULLAH SAW
}

\author{
Fahmi Sahlan \\ Universitas Bhayangkara Jakarta Raya \\ Email:fahmiisahlan@gmail.com
}

\begin{abstract}
Abstrak
Hadis sebagai suatu second hukum dari al-Quran. Di dalamnya terdapat aspek kehidupan Rasul yang menjadikan rujukan untuk pengikutnya, termasuk dari segi pendidikan. Pendidikan dan pembelajaran Rasul berbeda-beda dari segi metodologi sesuai konteks sosial yang terjadi. Beragam metodologi yang diberikan oleh Rasul, dari metode ceramah sampai peragaan. Dimana metode ini dalam artikel ini dijelaskan dari segi sosoi-historis secara gamblang. Banyak yang diterapkan dalam praktek pendidikan di masa kini yang bersumber dari metodologi pembelajaran Rasul.

Dalam proses belajar mengajar, Rasulullah Saw, senantiasa memilih metode-metode yang dinilai efektif dan efisien, mudah dipahami dan dicerna akal, serta mudah diingat sesuai dengan porsi dan kapasitas intelektual peserta didik. Fenomena tersebut dapat kita buktikan ketika mengeksplorasikan beberapa hadits, mulai dari mempelajari teks-teksnya sampai membacanya dengan cermat, tentu akan banyak ditemukan model perkataan (pengajaran) beliau yang sangat variatif.
\end{abstract}

Kata Kunci : hadis, metodologi 


\section{Pendahuluan}

Sebagai suatu sistem tentu saja kegiatan belajar mengajar mengandung sejumlah komponen yang meliputi tujuan, bahan pelajaran, kegiatan belajar mengajar, metode, alat dan sumber serta evaluasi. ${ }^{1}$

Metode dalam kegiatan belajar mengajar merupakan komponen penting yang mempengaruhi kualitas pembelajaran. Secara umum, metode dapat kita artikan sebagai cara mengajarkan sesuatu. Cara itu mungkin baik dan mungkin juga tidak baik. Baik tidaknya suatu metode banyak tergantung kepada beberapa faktor. Faktor-faktor tersebut mungkin berupa situasi dan kondisi pemakai metode itu sendiri yang kurang memahami metode tersebut atau tidak cocok dengan seleranya, atau secara obyektif metodenya tidak cocok dengan kondisi dan obyek.

Seiring berkembangnya zaman, banyak sudah bermunculan metodemetode pembelajaran yang kesemuanya berkiblat kepada pemikiran barat. Berbagai macam metode dicoba untuk diterapkan agar dapat menghasilkan hasil yang maksimal dari sebuah proses belajar mengajar. Namun kenyataannya justru malah sebaliknya, kebobrokan moral menghantui generasi muda bangsa ini.

Sekarang ini sangat gencar penerapan metode belajar di mana siswa dituntut untuk berperan aktif dalam proses pembelajaran. Mereka yang mencari, menemukan dan mengembangkan pengetahuannya sendiri. Dengan dalih memanfaatkan kecanggihan teknologi mereka diberikan tugas untuk mencari materi yang akan dibahas dan didiskusikan di internet. Namun malah memberikan dampak yang sangat negatif bagi perkembangan mereka.

Ziauddin Sardar, sebagaimana penulis kutip dari materi kuliah umum yang disampaikan oleh Komaruddin, M.MPd., mengatakan bahwa : "abad informasi bukanlah merupakan rahmat bagi manusia”.

Hasil penelitian DKT Indonesia 2005, menunjukkan perilaku seksual remaja di 4 kota yaitu Jabodetabek, Bandung, Surabaya dan Medan berdasarkan norma yang dianut, $89 \%$ remaja tidak setuju adanya seks pra nikah, namum kenyataannya $82 \%$ remaja pernah melakukan seks pra nikah, $66 \%$ remaja punya teman hamil sebelum menikah. Remaja secara terbuka menyatakan melakukan seks pra nikah di Jabodetabek 51\%, Bandung 54\%, Surabaya 47\%, dan Medan 52\%. Dari data PKBI 2006 didapatkan bahwa kisaran umur pertama kali melakukan hubungan seks pada umur 13 - 18 tahun, $60 \%$ tidak menggunakan alkon, $85 \%$ dilakukan di rumah sendiri.

Menurut survey Komnas Perlindungan Anak di 33 Provinsi Januari s/d Juni 2008 menyimpulkan 1) 97\% remaja SMP dan SMA pernah menonton film porno, 2) 93,7\% remaja SMP dan SMA pernah ciuman, genital stimulation (meraba alat kelamin) dan oral sex (sex melalui mulut), 3) 62,7\% remaja SMP tidak perawan, 4) $21,2 \%$ remaja mengaku pernah aborsi. ${ }^{2}$

Bagaimana pun bagi kaum muslimin, al-Qur`an dan al-Sunnah merupakan sumber atau landasan bagi aktifitas berfikir mereka. Kedua sumber itu harus senantiasa difungsikan untuk menjadi pedoman atau juklak dalam menilai aktifitas berfikir mereka mulai dari kerangka berfikir, tujuan berfikir, cara-cara berfikir dan orientasi berfikirnya. Dari kedua sumber itulah bisa diketahui apakah

${ }^{1}$ Syaiful Bahri Djamara dan Aswan Zain, Strategi Belajar Mengajar, (Jakarta: Rineka Cipta, 1997), h. 48.

${ }^{2}$ Panduan Pengelolaan Panduan Informasi dan Konseling Remaja, (Jakarta; Kantor KB Kota Administrasi Jakarta Timur, 2011). h. 3-4. 
kegiatan berfikirnya mengarah pada hasil-hasil yang positif-konstruktif sesuai dengan ajaran-ajaran Islam, atau mengarah pada hasil-hasil negatif-destruktif yang bertentangan dengan ajaran Islam.

Berdasarkan fungsi al-qur`an dan al-Sunnah tersebut dalam kegiatan berfikir manusia muslim, maka tidak ada ilmu pengetahuan yang mengklaim dirinya sepenuhnya Islami, bila metodologi yang digunakan tetap berakar dari paradigma sains modern. Metode keilmuan ini harus diislamisasikan terlebih dahulu, sebab bagi orang-orang non Muslim Barat, metode itu menghasilkan ilmu yang bersifat netral, walaupun kebenarannya sudah dianggap objektif, namun objektivitas itu belum dapat diterima oleh Allah, karena kebenarannya hanya ditunjukkan atau diberitahukan dalam $\mathrm{Al}$-qur`an. ${ }^{3}$

Muhammad Qutb pernah mengatakan bahwa : sebaik-baik kalam adalah Kalâmullah (al-qur`an). Tetapi Kalâmullah saja belum dapat mengubah masyarakat dari buruk menjadi baik. Karenanya, di samping menurunkan KalamNya, Allah juga mengutus seorang Nabi saw untuk menerjemahkan kandungan Kalam Allah itu ke dalam kehidupan sehari-hari. Karenanya, ketika isteri Nabi saw Aisyah ditanya tentang akhlak Nabi saw, beliau menjawab, "Akhlak Nabi saw itu adalah al-qur`an". Artinya, apa yang terkandung dalam al-qur`an itu menjadi sikap dan perilaku Nabi saw sehari-hari. ${ }^{4}$

Dalam proses belajar mengajar, Rasulullah Saw, senantiasa memilih metode-metode yang dinilai efektif dan efisien, mudah dipahami dan dicerna akal, serta mudah diingat sesuai dengan porsi dan kapasitas intelektual peserta didik. Fenomena tersebut dapat kita buktikan ketika mengeksplorasikan beberapa hadits, mulai dari mempelajari teks-teksnya sampai membacanya dengan cermat, tentu akan banyak ditemukan model perkataan (pengajaran) beliau yang sangat variatif. $^{5}$

\section{Kajian Hadits Nabi Tentang Metodologi Pembelajaran}

Beberapa metode pembelajaran yang diajarkan oleh Nabi Muhammad dari beberapa hadis, salah satunya:

1. Metode Drill dan Eksperimen

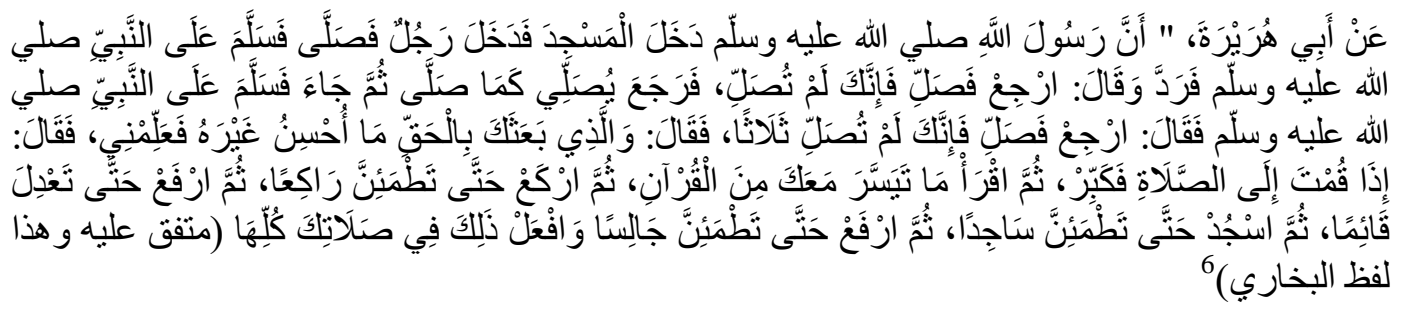

"Dari Abu Hurairah r.a. bahwa Rasulullah saw masuk ke masjid, kemudian ada seorang laki-laki masuk juga untuk melaksanakan shalat. Setelah shalat ia

\footnotetext{
${ }^{3}$ Mujamil Qomar, Epistimologi Pendidikan Islam Dari Metode Rasional Hingga Metode Kritik, (Jakarta: Erlangga), h. 119.

4 Ali Mustafa Yaqub, Sejarah dan Metode Dakwah Nabi, (Jakarta: Pustaka Firdaus, 2008), h. 226.

5 Nurdiansyah, "Karakteristik Metode Pembelajaran Dalam Hadits Tentang Air Laut", (Skripsi S1 Program Studi Pendidikan Agama Islam, STIT Al Marhalah Al 'Ulya, 2013), h. 6.

${ }^{6}$ Muhammad bin Isma'il al-Bukhari, Shahih Bukhari, (Beirut: Dar al-Fikr, 1981), vol. 1, h, 192.
} 
memberi salam kepada Nabi saw. Nabi pun menjawab dan bersabda: "Kembalilah, lalu shalat! Maka sesungguhnya engkau belum shalat". Laki-laki itu mengulangi shalat sebagaimana yang telah dilaksanakan. Kemudian memberi salam kepada Nabi, beliau bersabda lagi: "Kembalilah shalat, maka sesungguhnya engkau belum shalat”, sampai tiga kali. Lalu laki-laki itu berkata: "Demi Dzat Yang mengutusmu dengan kebenaran, aku tidak dapat memperbaiki shalat selainnya, maka ajarkanlah aku. Beliau bersabda: "Jika kamu berdiri akan shalat maka bertakbirlah kemudian bacalah apa yang mudah bersamamu daripada al-Qur'an, kemudian rukuklah sehingga tenang engkau dalam keadaan rukuk. Kemudian bangunlah hingga lurus engkau dalam keadaan berdiri. Kemudian sujudlah hingga engkau tenang dalam keadaan sujud. Kemudian bangunlah hingga engkau tenang dalam keadaan duduk. Dan lakukanlah itu dalam shalat-shalatmu semuanya". (HR. Bukhari dan Muslim. Dan ini lafazh Bukhari).

Metode pengajaran shalat yang dilakukan Nabi pada Hadits di atas dapat disebut metode drill dan eksperimen. Karena seorang laki-laki tersebut memperlihatkan bagaimana cara shalat yang benar dan berusaha melaksanakannya secara benar, sehingga diulang-ulang sampai tiga kali. Kemungkinan ia sudah pernah belajar dari orang lain tetapi belum memenuhi sasaran yang benar. Metode eksperimen di sini guru yakni Nabi saw bersama seorang sahabat tersebut sebagai muridnya mengerjakan cara shalat yang benar sebagai latihan praktis dari apa yang diketahui. Ia coba melakukan sesuai dengan pengetahuan dan kemampuannya, setelah tidak ada kemampuan memperbaiki shalatnya baru diluruskan oleh Nabi saw.

Metode ini juga disebut inkuiri (inquiry) arti harfiahnya adalah pertanyaan, pemeriksaan, dan penyelidikan. Maksudnya rangkaian pembelajaran yang menekankan pada proses berfikir secara kritis dan analisis untuk mencari dan menemukan sendiri jawaban dari satu masalah yang dipertanyakan. ${ }^{7}$

\section{Metode Tanya Jawab}

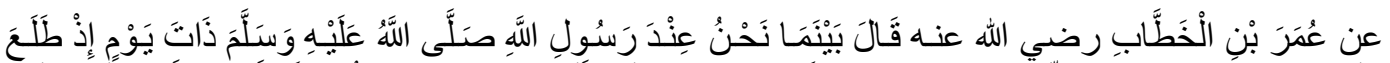

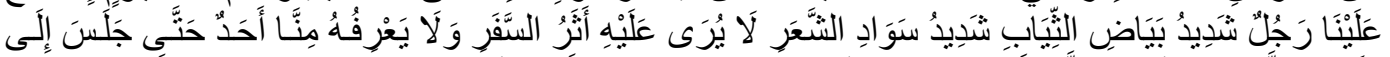

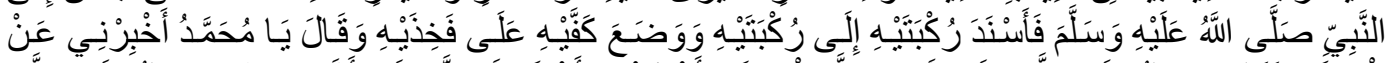

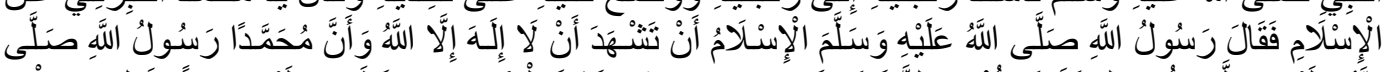

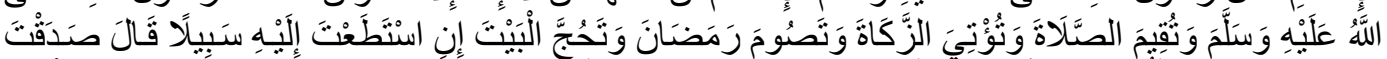

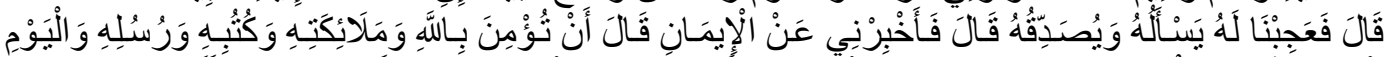

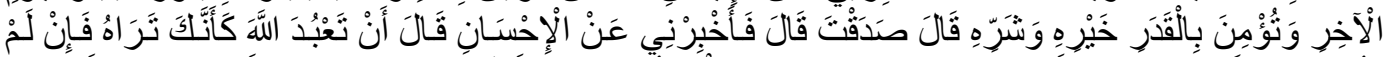

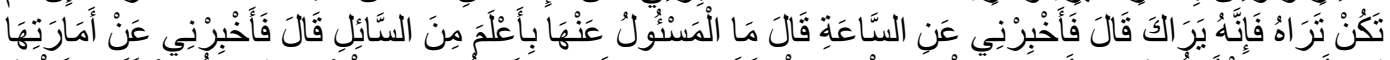

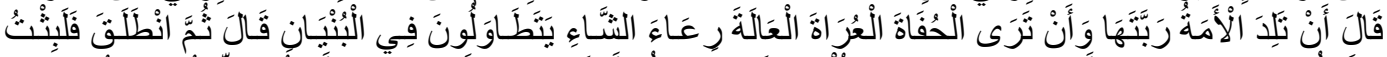

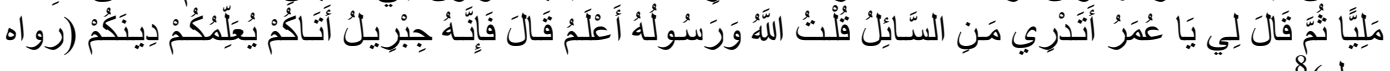

"Dari 'Umar bin al-Khathab r.a. berkata: Suatu hari ketika kami duduk bersama Rasulullah saw, tiba-tida datang seorang laki-laki kepada kami yang sangat putih pakaiannya, sangat hitam rambutnya, tidak tampak tanda-tanda bekas perjalanan di dirinya, dan tidak seorang pun di antara kami yang mengenalnya. Sehingga ia

\footnotetext{
${ }^{7}$ Ibid., h. 38.

${ }^{8}$ Muslim bin Hajjaj, Shahih Muslim, vol. 1, h. 28-29.
} 
duduk di hadapan Nabi saw, lalu ia menyandarkan dua lututnya pada dua lutut Nabi dan meletakkan kedua telapak tangannya ke atas kedua pahanya. Lalu berkata: "Hai Muhammad! Beritahukan aku tentang Islam”. Lalu Rasulullah saw menjawab: "Islam itu kamu bersaksi bahwa tidak ada Tuhan selain Allah dan bahwa Muhammad adalah utusan Allah, kamu mendirikan shalat, menunaikan zakat, puasa ramadhan, dan kamu berhaji ke baitullah jika kamu mampu". Lalu orang itu berkata "Kamu benar". 'Umar berkata: "Kami heran terhadapnya, dia bertanya dan dia yang membenarkannya". Lalu orang itu berkata lagi: "beritahukan aku tentang iman". Nabi menjawab: "Iman itu adalah kamu percaya kepada Allah, para malaikat-Nya, kitab-kitab-Nya, Rasul-Rasul-Nya, hari akhir, dan kamu percaya dengan takdir baik dan buruknya". Lalu dia berkata: "Kamu benar". Orang itu berkata lagi: "beritahukan aku tentang Ihsan". Nabi menjawab: "Ihsan adalah kamu menyembah Allah seakan-akan kamu melihat-Nya, namun jika kamu tidak dapat melihat-Nya, maka sesunggunya Dia melihatmu". Orang itu berkata lagi: "beritakanlah kepadaku tentang hari kiamat". Nabi menjawab: "Tidaklah orang yang ditanya tentang hari kiamat lebih tahu daripada yang bertanya". Lalu dia berkata lagi: "Beritahukan aku tentang tanda-tandanya". Nabi menjawab: "Jika seorang budak wanita melahirkan tuannya, dan kamu melihat orang yang berjalan tanpa alas kaki, telanjang, dan miskin berlomba membangun berbagai bangunan". lalu orang itu pergi, dan aku diam sejenak. Kemudian Nabi berkata kepadaku: "wahai 'Umar, tahukan kamu siapa yang bertanya?”. Aku berkata: "Allah dan Rasul-Nya lebih mengetahui". Nabi berkata: "Sesungguhnya itu adalah Jibril yang mendatangimu untuk mengajarkan agamamu”. (HR. Muslim).

Metode penyampaian pelajaran yang terkandung dalam Hadits ini adalah metode tanya jawab atau dialog antara Jibril dengan Nabi dan antara Nabi dengan sesama sahabat atau antara guru dengan murid dan antara murid dengan sesama murid, jadi terjadi interaktif atar-beberapa arah. ${ }^{9}$

\section{Metode Cerita atau Kisah}

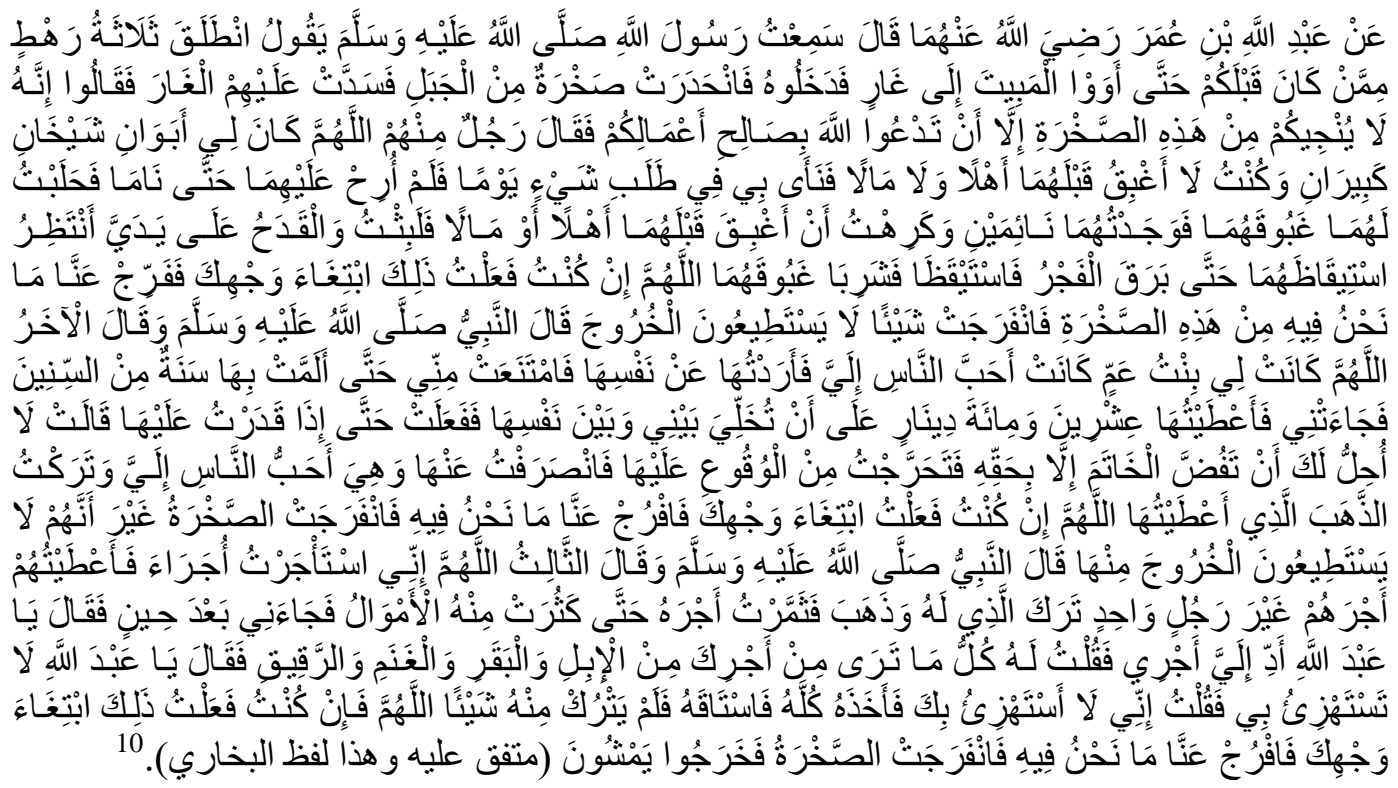

\footnotetext{
${ }^{9}$ Abdul Majid Khon, Hadis Tarbawi: Hadis-Hadis Pendidikan, h. 49-50.

${ }^{10}$ Muhammad bin Isma'il al-Bukhari, Shahih Bukhari, vol. 3, h, 51-52.
} 
"Dari Abdullah bin 'Umar r.a berkata: Aku mendengar Rasulullah saw bersabda: "Ada tiga orang dari ummat sebelummu yang melakukan bepergian, hingga mereka ingin bermalam di sebuah goa. Lalu mereka memasukinya. Tibatiba runtuh bebatuan dari atas gunung, sehingga menutup goa yang mereka berada di dalamnya. Kemudian salah seorang mereka ada yang berkata: "sesunggunya tidak akan ada yang bisa menyelamatkanmu dari bebatuan ini melainkan kamu berdo'a kepada Allah dengan ama-amal shalihmu. Lalu salah seorang mereka berkata seraya berdo'a: "Ya Allah aku memiliki dua orang tua yang sangat tua dan aku tidak pernah memberi minum susu (di malam hari) kepada siapapu sebelum memberi minum kepada keduanya. Aku lebih mendahulukan mereka berdua daripada keluarga dan budakku (hartaku). Kemudian pada suatu hari, aku mencari kayu di tempat yang jauh. Ketika aku pulang ternyata mereka berdua telah tertidur pulas. Aku pun enggan memberikan minuman tersebut kepada keluargaku atau budakku. Seterusnya aku menunggu hingga mereka terbangun dan ternyata mereka baru bangun setelah subuh, dan gelas minuman itu masih ada di tanganku. Kemudian mereka bangun dan meminum minuman tersebut. Ya Allah, jika aku lakukan itu semata karena mengharap ridho-Mu, maka lepaskanlah kesukarang yang sedang kami hadapi dar batu besar yang menutupi kami ini". Batu besar itu tida-tiba terbuka sedikit. Namun mereka masih belum dapat keluar dari goa. Lalu Nabi saw melanjutkan ceritanya dan berkata: "Berkata yang lainnya: "Ya Allah dahulu ada putri pamanku yang aku sangat menyukainya. Aku pun sangat menginginkannya. Namun ia menolak cintaku. Hingga berlalu beberapa tahun, ia mendatangiku. Lalu aku berikan ia 120 dinar dengan syarat ia mau berkhalwat berdua saja dengan aku (berzina). Dia pun mau melakukan itu, hingga ketika aku menguasainya, dia berkata: "Tidak halal bagimu membuka cincin kecuali dengan cara yang benar (nikah)". Aku pun langsung tercengang kaget dan pergi meninggalkannya padahal dialah yang paling aku cintai. Dan aku tinggalkan emas yang aku berikan padanya. Ya Allah jika itu aku lakukan semata karena mengharap ridho-Mu, maka lepaskanlah kesukaran kami dari batu besar ini”. Batu besar itu pun tiba-tiba terbuka lagi, namun mereka masih belum dapat keluar. Selanjutnya Nabi meneruskan ceritanya: "lalu berkata yang ketiga: "Ya Allah dahulu aku memperkerjakan beberapa pegawai dan aku berikan mereka gaji. Kecuali ada satu orang yang meninggalkan gajinya, lalu pergi. Kemudian aku kembangkan gajinya itu hingga menjadi harta yang banyak. Lalu suatu hari dia datang, seraya berkata: "Wahai Abdullah! Berikanlah gajiku”. Lalu aku berkata: "setiap apa yang kamu lihat daripada onta, sapi, kambing, dan budakbudak, itu adalah gajimu”. Dia pun berkata: "Wahai Abdullah, jangan kau mengejekku". Aku menjawab: "sesungguhnya aku tidaklah mengejekmu". Kemudian dia ambil semuanya dan tidak menyisakan sedikitpun. Ya Allah jika aku lakukan itu semata karena mengharap ridho-Mu, maka lepaskanlah kesukaran dari kami”. Tiba-tiba terbukalah batu besar itu. Dan mereka keluar dari goa." (HR. Bukhari dan Muslim).

Dalam Hadits ini Rasulullah saw menggunakan metode cerita. Beliau sebagai guru menceritakan sebuah kisah yang terjadi di masa lampau kepada muridnya, para sahabat. Setelah itu para sahabat mencerna dan menggali faedah sendiri dari apa yang terkandung dalam cerita tersebut. Tidak ada tanya jawab atau dialog di sini. Ini lah yang disebut dengan metode cerita atau kisah. 


\section{Metode Demonstrasi}

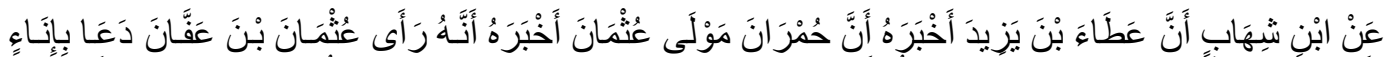

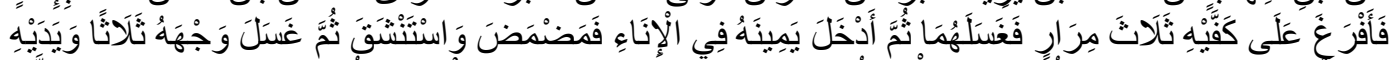

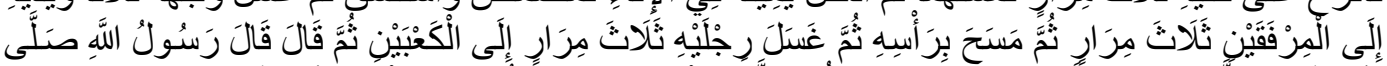

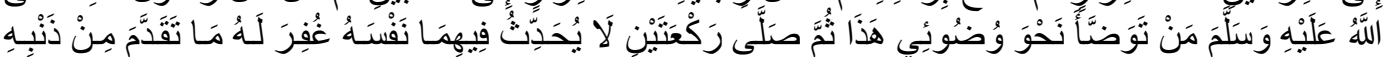

11 (متفق عليه وهذا لفظ البخارئَ

"Dari Ibnu Syihab berkata, "bahwa 'Atha' bin Yazid mengabarkan kepadanya bahwa Humran bekas budak Utsman mengabarkan kepadanya bahwa dia melihat Utsman bin Affan meminta sebuah bejana berisi air. Lalu dia menuangkan atas kedua telapak tangannya sebanyak tiga kali, lalu membasuhnya. Kemudian ia memasukkan tangan kanannya ke bejana itu lalu berkumur-kumur dan beristinsyaq. Kemudian membasuh mukanya sebanyak tiga kali dan kedua tangannya hingga dua sikunya tiga kali. Kemudian menyapu kepalanya. Kemudian membasuh kedua kakinya tiga kali hingga dua mata kakinya. Kemudian dia berkata, "Rasulullah saw bersabda, "Siapa orang yang berwudhu seperti wudhuku ini kemudian ia sholat dua rakaat yang dia tidak bercerita pada keduanya kepada dirinya, maka diampuni baginya apa yang telah lalu dari dosanya." (HR. Bukhari).

Dalam hadits ini Utsman bin Affan r.a mengajarkan Humran tata cara berwudhu dengan cara mendemonstrasikannya. Humran memperhatikan apa yang dilakukan Utsman bin Affan. Metode ini disebut dengan metode Demonstrasi, yaitu dimana Guru menunjukkan kepada siswa dengan cara mempraktekkan langsung di hadapan mereka. Metode pembelajaran seperti ini banyak kita jumpai pada hadits-hadits Nabi saw, lebih-lebih dalam hal ibadah praktek seperti wudhu, tayammum, sholat, dan lain sebagainya.

\section{Metode Expository dan Discovery}

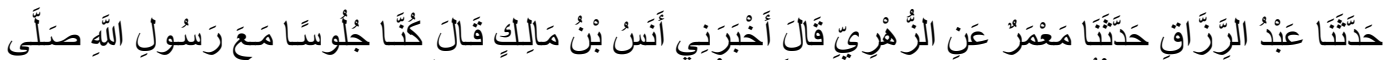

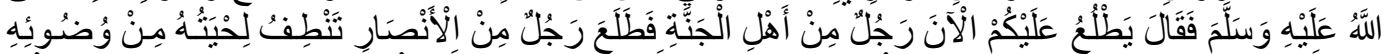

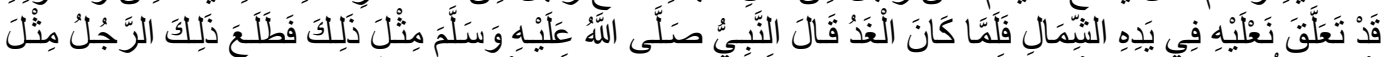

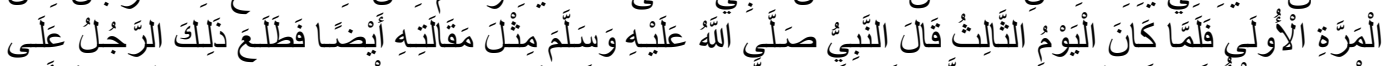

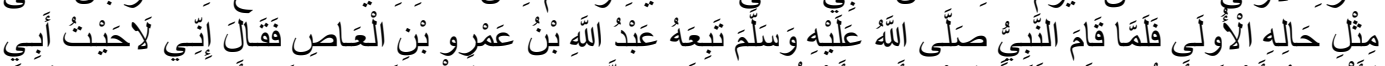

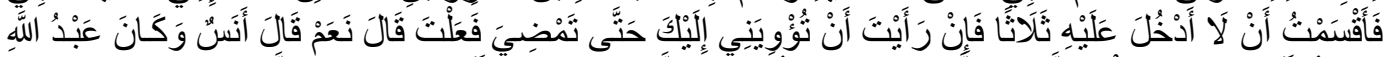

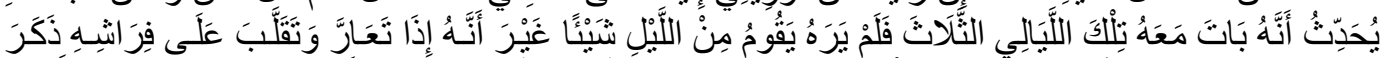

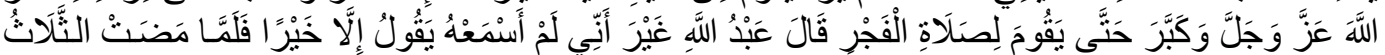

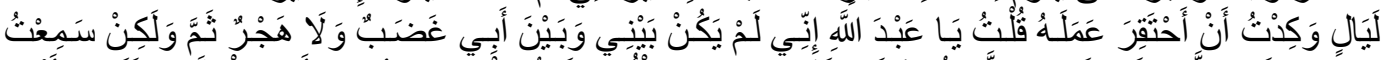

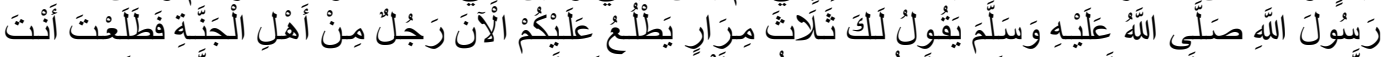

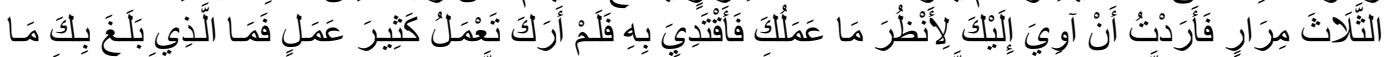

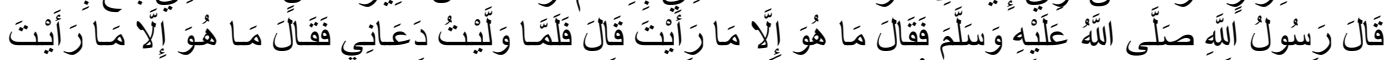

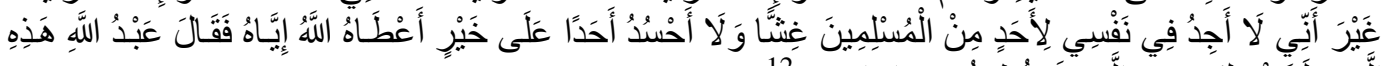

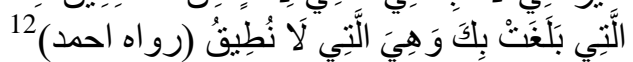

"Dari Anas bin Malik berkata: "dahulu kami sedang duduk bersama Rasulullah saw, lalu beliau bersabda: "akan muncul kepada kalian sekarang

\footnotetext{
${ }^{11}$ Muhammad bin Isma'il al-Bukhari, Shahih Bukhari, vol. 1, h. 48.

${ }^{12}$ Ahmad bin Hanbal, Musnad al-Imam Ahmad bin Hanbal, (Beirut: Dar Shodir), vol. 3, h. 166 .
} 
seseorang yang termasuk dari penghuni surga”. Kemudian muncullah seorang laki-laki dari golongan anshor yang menetes dari jenggotnya bekas air wudhu, dan bergantung dua sandalnya di tangan kirinya. Keesokan harinya, Nabi saw bersabda seperti yang diucapkan kemarin. Lalu muncullah orang tersebut seperti halnya pertama kali muncul. Ketika di hari ketiga, Nabi bersabda seperti sabdanya pada hari pertama. Lalu muncullah orang itu seperti halnya di hari pertama. Kemudian ketika Nabi saw bangun dari duduknya, Abdullah bin 'Amr bin al-'Ash mengikutinya. Lalu ia berkata kepada laki-laki itu, "sesungguhnya aku sedang berselisih dengan ayahku, dan aku berjanji tidak akan menemuinya selama tiga hari. Apabila menurutmu aku boleh bermalam di rumahmu hingga berlalu tiga hari, maka lakukanlah". Laki-laki itu menjawab,: "Ya". Anas berkata: "sesunguhnya Abdullah bercerita bahwa ia bermalam bersama laki-laki itu selama tiga malam. Namun dia tidak pernah melihatnya bangun malam. Akan tetapi, jika dia membalikkan tubuhnya di atas tempat tidur, dia selalu mengingat Allah dan bertakbir, hingga bangun untuk shalat fajar. Abdullah berkata: "Aku tidak pernah mendengar dia mengatakan sesuatu kecuali kebaikan. Maka ketika berlalu tiga malam dan aku hampir mencela (menghina) amal perbuatannya, aku pun berkata: "Wahai Hamba Allah! Sesungguhnya aku dan ayahku tak pernah marah. Dan aku tak pernah ingin berpisah darinya. Namum aku mendengar Rasulullah saw bersabda tentangmu sebanyak tiga kali "akan muncul kepada kalian sekarang seorang yang termasuk dari pernghuni surga”. Kemudia engkau pun muncul sebanyak tiga kali itu. Maka aku ingin bermalam bersamamu untuk melihat apa amal perbuatanmu. Lalu aku memperhatikan amalmu, dan aku tidak melihat kamu banyak beramal. Lalu apa yang membuatmu sampai pada derajat apa yang dikatakan oleh Rasulullah saw?". Kemudian ia menjawab: "amalku tidak lebih dari apa yang kamu lihat". Tatkala aku berpaling hendak meninggalkannya, dia memanggilku, lalu berkata: "amalku tidak lebih dari apa yang kamu lihat, melainkan aku tidak pernah mendapati dalam diriku sedikitpun kebencian terhadap sesama muslim dan aku tidak pernah iri hati kepada siapapun yang Allah berikan kebaikan kepadanya”. Abdullah pun berkata: "Itulah yang menyebabkan engkau mendapatkan derajat itu. Dan kami belum mampu”. (HR. Ahmad)

Terkadang Rasulullah saw membuat samar suatu permasalahan agar orang yang mendengar berusaha untuk mengetahuinya sehingga lebih mengena bagi dirinya dan lebih memotivasi dirinya untuk mengerjakannya. ${ }^{13}$

Siswa hanya menerima saja informasi yang diberikan oleh guru. Pengajaran telah diolah oleh guru sehingga siap disampaikan kepada siswa dan siswa diharapkan belajar dari informasi yang diterimanya itu, disebut ekspositorik. $^{14}$

\section{Contextual Teaching Learning}

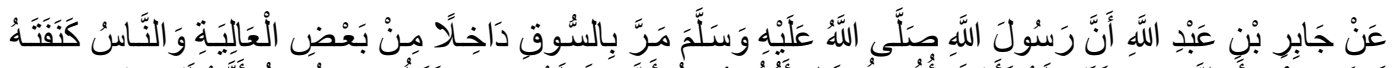

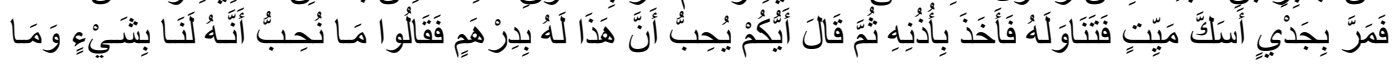

${ }^{13}$ Abdul Fattah Abu Ghuddah, al-Rasul al-Mu'allim wa Asalib fi al-Ta'lim, penerjemah Umar Husein Assegaf, Mendidik dan Mengajar Ala Rasulullah saw, (Bantul: Layar Publishing, 2015), h. 103.

14 Buchari Alma, dkk., GURU PROFESIONAL (Menguasai Metode dan Terampil Mengajar), (Bandung: Alfabeta, 2010), h. 48. 


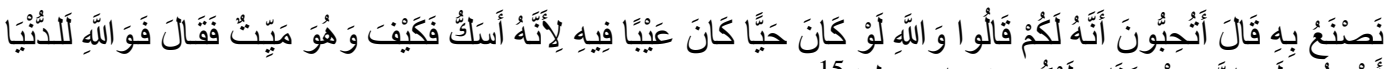

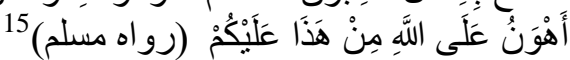

"Dari Jabir bin Abdullah bahwa Rasulullah saw melewati sebuah pasar masuk melalui salah satu pintu Madinah, dan masyarakat berada di sekitarnya. Lalu ada orang yang lewat membawa anak kambing yang cacat dan sudah menjadi bangkai. Kemudian diambil oleh Nabi saw dua telinganya (untuk ditunjukkan). Lalu Nabi bersabda: "adakah diantara kalian yang mau membeli ini dengan harga satu dirham?". Mereka menjwab: "kami tidak suka menjadikan itu milik kami sedikitpun, apa yang akan kami lakukan dengan anak kambing (cacat dan bangkai) itu?". Rasul bersabda: "apakah kalian mau bahwa anak kambing ini menjadi milik kalian (gratis)?”. Mereka menjawab: "Demi Allah! Kalaulah anak kambing itu masih hidup, sungguh terdapat cacat dalam dirinya. Bagaimana dia sekarng sudah menjadi bangkai?". Lalu Rasulullah saw bersabda: "Demi Allah! Sesungguhnya dunia ini lebih hina di sisi Allah dari (anak kambing) ini untukmu”. (HR. Muslim).

Dalam Hadits ini Rasulullah menjadikan objek yang sedang terjadi saat itu sebagai materi pembelajaran. Yaitu objek anak kambing yang sudah menjadi bangkai dijadikan perumpamaan dunia yang penuh dengan kehinaan.

\section{Metode Analogi}

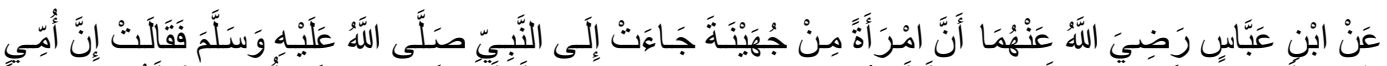

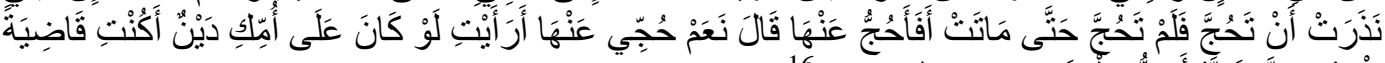

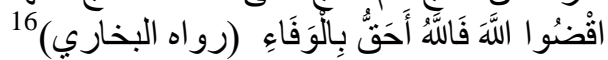

"Dari Ibnu Abbas r.a. bahwa seorang wanita dari Juhainah datang menemui Nabi saw. Lalu ia berkata: "Sesungguhnya ibuku pernah bernazar untuk melaksanakan haji. Apakah aku harus menggantikan hajinya?”. Rasul menjawab: "Ya, berhajillah menggantikannya. Coba jika ibumu memiliki hutang, apakah engkau akan membayarnya? Tunaikanlah kepada Allah, sesungguhnya Allah yang paling berhak ditunaikan". (HR. Bukhari).

Terkadang Rasulullah saw memberikan perbandingan hukum kepada sahabatnya dan melontarkan sebabnya jika muncul keraguan dan kesulitan dalam penentuan hukumnya. Sehingga akan menjadi jelas perkara yang ragu dan samar pemahamannya. Melalui sistem perbandingan ini mereka dapat mengetahui pedoman dan maksud syari'at serta memahami tujuannya yang jauh. ${ }^{17}$

\section{Metode Peragaan}

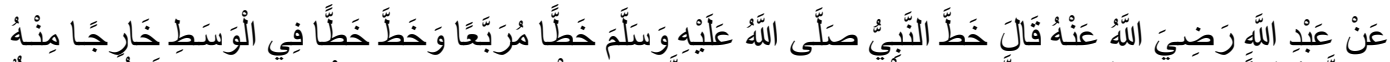

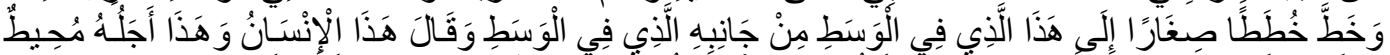

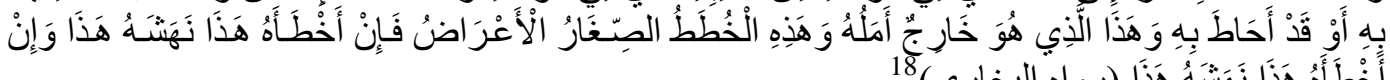

"Dari Abdullah r.a berkata, "Nabi saw menggambar segi empat dan satu garis lurus di tengah segi empat itu sampai keluar. Lalu menggambar garis-garis kecil di sebelah garis tengah sampai berakhir (selesai). Kemudian sambil

\footnotetext{
${ }^{15}$ Muslim bin Hajjaj, Shahih Muslim, vol. 8, h. 201-202.

${ }^{16}$ Muhammad bin Isma'il al-Bukhari, Shahih Bukhari, vol. 2, h. 217-218.

${ }^{17}$ Abdul Fattah Abu Ghuddah, al-Rasul al-Mu'allim wa Asalib fi al-Ta'lim, penerjemah Umar Husein Assegaf, Mendidik dan Mengajar Ala Rasulullah saw, h. 56.

${ }^{18}$ Muhammad bin Isma'il al-Bukhari, Shahih Bukhari, vol. 7, h. 171.
} 
menunjuk gambar itu beliau bersabda, "ini adalah manusia. Dan ini adalah ajalnya yang mengelilinginya. Garis lurus keluar ini adalah cita-cita dan harapannya. Sedang garis kecil ini adalah problematika hidup (tantangan) yang dihadapinya. Kalau ia lepas dari yang satu, ia akan dihadang oleh yang lain, dan seterusnya". (HR. Bukhari).

Rasulullah menggunakan gambar sebagai media pembelajaran. Tujuannya adalah untuk mempermudah murid memahami sesuatu. Penggambaran tentang manusia, ajal dan angan-angannya adalah sesuatu yang abstrak lalu diperjelas dengan sesuatu yang konkret, yaitu berupa gambar. Dengan media gambar inilah diharapkan akan memudahkan murid dalam memahami apa yang dimaksud oleh si guru.

\section{Kesimpulan}

Metodologi pembelajaran Rasul memang beragam dan tidak satu metode dalam menyampaikan materi, sehingga metode pembelajaran harus dilihat dari konteks social, psikologi, dll sehingga subtansi isi bisa dipahami kepada penerima (dalam hal ini sahabat).

\section{Daftar Pustaka}

Djamara, Syaiful Bahri dan Aswan Zain, Strategi Belajar Mengajar, Jakarta: Rineka Cipta, 1997

Panduan Pengelolaan Panduan Informasi dan Konseling Remaja, Jakarta; Kantor KB Kota Administrasi Jakarta Timur, 2011

Qomar, Mujamil, Epistimologi Pendidikan Islam Dari Metode Rasional Hingga Metode Kritik, Jakarta: Erlangga

Yaqub, Ali Mustafa, Sejarah dan Metode Dakwah Nabi, Jakarta: Pustaka Firdaus, 2008

Nurdiansyah, "Karakteristik Metode Pembelajaran Dalam Hadits Tentang Air Laut”, Skripsi S1 Program Studi Pendidikan Agama Islam, STIT Al Marhalah Al 'Ulya, 2013

al-Bukhari, Muhammad bin Isma'il, Shahih Bukhari, Beirut: Dar al-Fikr, 1981

Hajjaj, Muslim bin, Shahih Muslim, vol. 1

Khon, Abdul Majid, Hadis Tarbawi: Hadis-Hadis Pendidikan

al-Bukhari, Muhammad bin Isma'il, Shahih Bukhari, vol. 3

al-Bukhari, Muhammad bin Isma'il, Shahih Bukhari, vol. 1

Hanbal, Ahmad bin, Musnad al-Imam Ahmad bin Hanbal, (Beirut: Dar Shodir), vol. 3

Ghuddah, Abdul Fattah Abu, al-Rasul al-Mu'allim wa Asalib fi al-Ta'lim, penerjemah Umar Husein Assegaf, Mendidik dan Mengajar Ala Rasulullah saw, Bantul: Layar Publishing, 2015

Alma, Buchari, dkk., GURU PROFESIONAL (Menguasai Metode dan Terampil Mengajar), Bandung: Alfabeta, 2010

Hajjaj, Muslim bin, Shahih Muslim, vol. 8

al-Bukhari, Muhammad bin Isma'il, Shahih Bukhari, vol. 2

Ghuddah, Abdul Fattah Abu, al-Rasul al-Mu'allim wa Asalib fi al-Ta'lim, penerjemah Umar Husein Assegaf, Mendidik dan Mengajar Ala Rasulullah saw

al-Bukhari, Muhammad bin Isma'il, Shahih Bukhari, vol. 7. 